\title{
Article \\ Sorption of Fulvic Acids and Their Compounds with Heavy Metal Ions on Clay Minerals
}

\author{
Maria Nikishina ${ }^{1}$, Leonid Perelomov ${ }^{1, * \mathbb{C}}$, Yury Atroshchenko ${ }^{1}$, Evgenia Ivanova ${ }^{1}$, Loik Mukhtorov ${ }^{1}$ \\ and Peter Tolstoy ${ }^{2}$ (i) \\ 1 Faculty of Natural Sciences, Tula State Lev Tolstoy Pedagogical University, 300026 Tula, Russia; \\ mama-67@mail.ru (M.N.); reaktiv@tsput.ru (Y.A.); omela005@gmail.com (E.I.); mukhtorov.loik@mail.ru (L.M.) \\ 2 Department of Physical Organic Chemistry, Institute of Chemistry, St. Petersburg State University, \\ 198504 St. Petersburg, Russia; peter.tolstoy@spbu.ru \\ * Correspondence: perelomov@rambler.ru; Tel.: +7-910-552-99-45
}

Citation: Nikishina, M.; Perelomov, L.; Atroshchenko, Y.; Ivanova, E.; Mukhtorov, L.; Tolstoy, P. Sorption of Fulvic Acids and Their Compounds with Heavy Metal Ions on Clay Minerals. Soil Syst. 2022, 6, 2. https://doi.org/10.3390/ soilsystems 6010002

Academic Editor: Baoshan Xing

Received: 5 December 2021

Accepted: 31 December 2021

Published: 2 January 2022

Publisher's Note: MDPI stays neutral with regard to jurisdictional claims in published maps and institutional affiliations.

Copyright: (C) 2022 by the authors. Licensee MDPI, Basel, Switzerland. This article is an open access article distributed under the terms and conditions of the Creative Commons Attribution (CC BY) license (https:// creativecommons.org/licenses/by/ $4.0 /)$.

\begin{abstract}
In real soils the interaction of humic substances with clay minerals often occurs with the participation of metal cations. The adsorption of fulvic acids (FA) solution and their solutions in the presence of heavy metal ions ( $\mathrm{Pb}$ or $\mathrm{Zn}$ ) on two clay minerals (kaolinite and bentonite) was investigated by measurement of the optical density changes in the of equilibrium solutions. The FA adsorption by bentonite at the concentrations $0.05-1 \mathrm{~g} / \mathrm{L}$ proceeds according to the polymolecular mechanism and has a stepwise character. The adsorption of FA on kaolinite can be described by the mechanism of monomolecular adsorption. In three-component systems, including FA, trace element ions and a clay mineral, complex processes occur, including the formation of complexes and salts and their adsorption. The sorption of colored complexes of FA with $\mathrm{Pb}$ on the surface of kaolinite and bentonite increases with increasing metal concentrations $(0.5-2 \mathrm{mmol} / \mathrm{L})$. The interaction of the FA- $\mathrm{Zn}^{2+}$ compounds with bentonite is a more complicated process-adsorption takes place at the lowest concentration used only. Thus, binding of FA by clay minerals in the presence of metal cations is a complex phenomenon due to the chemical heterogeneity of FA, different properties of metals, characteristics of mineral surfaces and the variability of environmental conditions.
\end{abstract}

Keywords: humic substances; lead; zinc; bentonite; kaolinite; ternary systems; adsorption

\section{Introduction}

Clay minerals and humic substances are one of the most important components controlling the accumulation, mobility and bioavailability of nutrients and pollutants in soils [1,2]. The composition and properties of these components and their interactions with each other affect the formation of the soil structure, the adsorption and transfer of nutrients and pollutants, and the development of erosion processes [3]. The interaction of clay minerals with humic substances is a complex process that depends on the properties of the mineral and organic matter, as well as the soil and ecological conditions in which their interaction takes place.

Most clay minerals' outer and inner surfaces are polar and hydrophilic, resulting in high affinities towards, mainly cationic, organic substances. The cation exchange capacity (CEC) of kaolinite varies from 1 to $10 \mathrm{mg}$ equiv $/ 100 \mathrm{~g}$ over a small area of the specific surface $\left(7-30 \mathrm{~m}^{2} / \mathrm{g}\right)$ [4]. The total specific surface of smectite clays is $450-850 \mathrm{~m}^{2} / \mathrm{g}$ and the outer specific surface is as much as $40-70 \mathrm{~m}^{2} / \mathrm{g}[5,6]$. The CEC for smectites determined by the traditional methods is $65-135 \mathrm{cmol}$ equiv $/ \mathrm{kg}$ [7]. The anionic substance-adsorbing capacity of clay minerals is lower: not more than $2 \mathrm{cmol} / \mathrm{kg}$ for kaolinites and less than $5 \mathrm{cmol} / \mathrm{kg}$ for smectites [8].

Humic acid and fulvic acid (FA) adsorb on the surface of clay particles and may alter their surface properties, forming chemical compounds and intermolecular agglomerates, built due to hydrogen bonds and other long-range forces [9]. It was shown that the 
most stable mineral-organic surface compounds (clusters and matrices) are formed at the interaction of carboxylic acids with positively charged surface sites. This also significantly modifies the hydrophilic-hydrophobic properties of the mineral surface $[10,11]$.

Under natural conditions, only FA or low-molecular-weight fractions of HA can participate in the reactions of adsorption interaction with clays, while the interaction of high-molecular-weight components of humus with soil minerals should be hindered by their low solubility. The authors showed that for a wide range of soil solutions, from 16 to $60 \%$ of dissolved organic matter comprised humic substances [12,13], consisting mainly of fulvic acids [13]. Fulvic acids are an important class of soil organic matter. They occur in soils mainly as a result of plant decay and are soluble at all $\mathrm{pH}$ levels [14]. FAs stimulate plant growth, especially with foliar spraying. However, there is often a maximum level of plant exposure to FA above which growth stimulation decreases, with FA even becoming toxic [15].

Currently, there are a large number of studies devoted to the effect of humic substances on the adsorption of heavy metals by clay minerals, because the metals are important contaminants of the environment [16]. The behavior of the metal ions in the ternary system consisting of the metal cations, fulvic acids anions and the mineral is governed by the following reactions: (1) the adsorption of the free metal cations by the surface of the mineral, (2) the adsorption of the free metal cations by the mineral's surface modified by the fulvic acid anions, (3) the formation of metal salts and complexes with fulvic acids, and (4) the adsorption of free and charged metal salts and complexes on the modified and unmodified clay mineral surfaces [17]. In this case, the adsorption of the complexes on the mineral surface can occur through the interaction of the metal with the surface, and through the organic ligand [18].

The problem of the influence of different metal cations on the fulvic acid adsorption by the minerals has been much less studied. At the same time, this problem is of great interest from the point of view of the processes occurring in soils and other environments enriched by humic substances. Soil organic acids and their compounds with metal cations have a different chemical affinity for the surfaces of the clay minerals, and the mechanism of their interaction with the surfaces can also change [16]. The adsorption density of FA onto the natural oxide was significantly improved after adding the metal cations. The XPS analysis and SEM imaging indicated that the metal cations served as a bridge between FA molecules and the surface of the oxide, so that the adsorption of FA onto the mineral was promoted. In addition, the viscosity of FA increased after adding the metal cations [19]. The experimental results showed that the presence of FA promotes Eu (III) adsorption by silica surface at acidic $\mathrm{pH}$ values, but decreases it at basic $\mathrm{pH}$ values, which indicates the formation of ternary surface complexes. Modeling calculations have shown that two ternary surface complexes are required to describe the experimental results in which the cation acts as a bridge between the surface site and FA [20]. Interaction of fulvic acid with $\mathrm{Cu}^{2+}$-montmorillonite at acidic $\mathrm{pH}$ sufficiently increased the interlamellar spacing of the mineral. The extent of interlayer adsorption decreased with increased $\mathrm{pH}$. Fulvic acid was also retained on external clay surfaces. The FA was held so tightly by the $\mathrm{Cu}^{2+}$-clay that $>3 / 4$ of the total amount adsorbed, including degradation products formed from it, resisted decomposition even when heated to $1000^{\circ} \mathrm{C}$. Reactions of FA in aqueous solutions with metal ions in the presence of clays differ from those in the absence of clay. Montmorillonite appears to affect the conformation of the fulvic acid polymer in a way that favors reactions between $\mathrm{C}=\mathrm{O}$ groups and metal ions [21].

This paper presents the results the adsorption of peat's fulvic acids on two clay minerals (kaolinite and bentonite) in the presence of increasing concentrations of heavy metal cations $(\mathrm{Pb}$ or $\mathrm{Zn})$ investigated by measurement of the optical density changes in the of equilibrium solutions. 


\section{Materials and Methods}

\subsection{Study Objects}

Na-bentonite of the Sarigyukh deposit (Armenia) was used for adsorption experiments. The mineral was provided by BentoGroupMinerals (Moscow). The manufacturer indicates the following oxide composition of the commercial mineral: $\mathrm{SiO}_{2}-58.25 \%, \mathrm{Al}_{2} \mathrm{O}_{3}-14.27 \%$, $\mathrm{Fe}_{2} \mathrm{O}_{3}-4.37 \%, \mathrm{MgO}-3.62 \%, \mathrm{Na}_{2} \mathrm{O}-2.25 \%, \mathrm{~K}_{2} \mathrm{O}-1.20 \%, \mathrm{CaO}-2.07 \%$. CEC of bentonite is $105 \mathrm{cmol}$ equiv $/ \mathrm{kg}$ and the $\mathrm{pH}$ of the aqueous suspension is 9.6. The mineralogical composition of bentonite and kaolinite was studied by X-ray diffractometry on a DRON-3 diffractometer $\left(\mathrm{CuK} \alpha\right.$ radiation, with a step of $0.1^{\circ}$ and a scan time of $\left.10 \mathrm{~s}\right)$. The mineral contains a high content of montmorillonite, minor impurities of quartz and feldspars.

We used kaolin from the Prosyanovskoe deposit (Ukraine). The data of X-ray diffraction analysis of kaolin confirm the high content of kaolinite in the mineral and the presence of impurities of mica (1-2\%), quartz, and feldspars. The $\mathrm{pH}$ of the aqueous extract is 9.2. According to the manufacturer, the mineral has the following oxide composition $\mathrm{SiO}_{2}-46.9 \%$, $\mathrm{TiO}-0.8 \%, \mathrm{Al}_{2} \mathrm{O}_{3}-38 \%, \mathrm{Fe}_{2} \mathrm{O}_{3}-0.6 \%, \mathrm{CaO}-0.39 \%, \mathrm{MgO}-0.05 \%$.

FA was extracted from a eutrophic peat (Tula region, Russia). Crushed and sifted through a 2-mm-sieve, peat was treated several times with a mixture of benzene-ethanol $(1: 1)$ in a ratio of peat/extractant $=1: 3$ [22]. For an exhaustive debituminization, the treatment was carried out until the extractable solution became almost colorless. After the extraction, the peat was dried at a temperature of $60{ }^{\circ} \mathrm{C}$ until the smell of benzene disappeared. Then, the peat was mixed with a solution of $0.1 \mathrm{M} \mathrm{NaOH}$ in the ratio of $1: 10$, kept on a water bath at $90{ }^{\circ} \mathrm{C}$ for $3 \mathrm{~h}$, and stored undisturbed overnight. The alkaline solution was decanted and filtered. The extraction was repeated several times, and the solution was collected and pooled together. Afterward, the alkaline extract obtained was acidified with $6 \mathrm{M} \mathrm{HCl}$ to $\mathrm{pH} 1.5$ and the humic acids were separated from FA by filtration. The FA solution was placed in dialysis bags and kept in distilled water until a negative reaction to chlorides with $\mathrm{AgNO}_{3}$ occurred. Then the solution of FA was dried over anhydrous $\mathrm{CaCl}_{2}$ at $20{ }^{\circ} \mathrm{C}$ to constant weight and ground in an agate mortar to a finely mixed state.

The FT-IR spectra were obtained by the application of the KBr pellet technique (mass of the sample $-0.002 \mathrm{~g} ; \mathrm{KBr}$ mass $-0.2 \mathrm{~g}$ ) and by the use of a Nicolet Model 7199 spectrometer operating at nominal resolutions of 4 and $2 \mathrm{~cm}^{-1}$.

The distribution of FA C between the structural fragments was determined by ${ }^{13} \mathrm{C}$ NMR spectroscopy. The NMR characterization was performed at the Resource Center for Magnetic Resonance Research Methods of the St. Petersburg State University using the Bruker Avance 400 WB device with a standard dual-channel sensor with a rotation system at a magic angle. A zirconium oxide rotor $(4 \mathrm{~mm})$ was used. The rotational frequency was set 12,500 Hz. To obtain the FA spectra, two methods were used: (1) the direct excitation method (the number of scans was 5000, the duration of the exciting pulse was $3.2 \mu$ s, and the relaxation delay was $10 \mathrm{~s}$ ) and (2) the cross-polarization/rotation method at a magic angle-CP/MAS (the number of scans was 2500, the contact duration was $500 \mu$ s, and the relaxation delay was $3 \mathrm{~s}$ ). To estimate the sufficient relaxation delay, several preliminary measurements were carried out. It turned out that for the one-pulse sequence the 10 s delay resulted in the spectrum virtually coinciding with that measured using longer relaxation delays. The relatively short spin-lattice relaxation times might be due to the presence of residual amounts of paramagnetic impurities remaining in the fulvic acid samples even after extraction, which is not uncommon for natural substances. For cross-polarization experiments, the selection of the relaxation delay was carried out in a similar way and it was found that $3 \mathrm{~s}$ delay is sufficient for complete relaxation of the excited nuclei. In turn, the duration of the contact time was selected in such a way that the line shapes and intensities in the CP/MAS spectrum were closest to those in the one-pulse experiment. Thus, it can be concluded that the analysis of the integral intensities in the obtained spectra provides estimates of the content of various functional groups of FA with a high degree of reliability. Processing of the ${ }^{13} \mathrm{C}$ NMR spectra of FA samples, including phase, baseline (for 
direct excitation method), and manual integration adjustments, was performed using the ACD Labs program.

\subsection{Adsorption Experiments}

To study the adsorption of FA on the clay minerals, their solutions in water with concentrations of $0.05 \mathrm{~g} / \mathrm{L}, 0.1 \mathrm{~g} / \mathrm{L}, 0.5 \mathrm{~g} / \mathrm{L}, 1 \mathrm{~g} / \mathrm{L}$ at an initial $\mathrm{pH} 4$ were used. Adsorption of FA in the systems FA- $\mathrm{Pb}^{2+}$-bentonite (or kaolinite), $\mathrm{FA}-\mathrm{Zn}^{2+}$-bentonite (or kaolinite) with increasing concentrations of metal ions and constant FA concentration was also investigated. The concentrations of metal salts $\left(\left(\mathrm{Pb}\left(\mathrm{NO}_{3}\right)_{2}\right.\right.$ or $\left.\mathrm{Zn}\left(\mathrm{NO}_{3}\right)_{2}\right) 0.5 \mathrm{mmol} / \mathrm{L}$, $1 \mathrm{mmol} / \mathrm{L}, 2 \mathrm{mmol} / \mathrm{L}$ were used. The FA concentration in all cases was $1 \mathrm{~g} / \mathrm{L}$. The experiments were carried out at a solid to liquid ratio of 1:100 (0.2 g of adsorbent and $20 \mathrm{~mL}$ of solution) for $4 \mathrm{~h}$ at a continuous shaking. At the end of the process, the solutions were filtered through a paper filter and then using a membrane syringe filter with a pore diameter of $0.45 \mu \mathrm{m}$.

The adsorption of FA on clay minerals was studied by changing the optical density of solutions with the UV-VIS spectrophotometer ПЭ-5300ви(Russia). The optical density of the equilibrium solutions of FA and FA-metal complexes was read at $465 \mathrm{~nm}$ wavelength. The amount of adsorbed FA was found from the difference between the initial and equilibrium concentrations, which were determined from the calibration graph in coordinates: $\mathrm{D}_{465}-\mathrm{C}$, where $\mathrm{C}$ is the FA concentration $(\mathrm{g} / \mathrm{L})$, and $\mathrm{D}_{465}$ is the optical density at $465 \mathrm{~nm}$ (the optical density was measured with respect to distilled water) [23].

All the experiments were performed in triplicate. Statistical processing of the results was carried out using STATISTICA 10.0 software, and the averages with standard deviations are presented. Determination of the statistical significance of differences between the mean values was performed using the Mann-Whitney U-test, and the values were considered significant at a significance level of $p<0.05$.

\section{Results}

The studied FA are characterized by typical absorption bands of IR spectra of various intensities typical for fulvic acids regardless of their origin [24,25]. A broad band with an absorption maximum of $\sim 3259 \mathrm{~cm}^{-1}$ indicates the presence of hydroxyl groups linked by hydrogen bonds. The hydroxyl group and the $=\mathrm{C}-\mathrm{O}-$ group also cause a band with a maximum at $1227 \mathrm{~cm}^{-1}$. The maximum at $2936 \mathrm{~cm}^{-1}$ may indicate both stretching vibrations of $\mathrm{O}-\mathrm{H}$ bounds and methyl and methylene groups. In the region of $1700-1720 \mathrm{~cm}^{-1}$ (with a maximum of $1713 \mathrm{~cm}^{-1}$ ), stretching vibrations of the $\mathrm{C}=\mathrm{O}$ bond of carboxylic acids are recorded. The band with a maximum at $1405 \mathrm{~cm}^{-1}$ indicates symmetric vibrations of carboxylate ions, with maxima at $1558 \mathrm{~cm}^{-1}$ at $1634 \mathrm{~cm}^{-1}$ - their asymmetric vibrations characterizing the stretching vibrations of the $\mathrm{C}=\mathrm{O}$ bond in undissociated carboxyl groups and esters. However, the band at $1634 \mathrm{~cm}^{-1}$ can also characterize the presence of aromatic fragments and peptide bonds in the molecules. The band of bending vibrations with a maximum at $1030 \mathrm{~cm}^{-1}$ can characterize the $\mathrm{C}-\mathrm{O}$ bonds of cyclic and aliphatic ethers and alcohols, as well as the possible presence of polysaccharides, which is confirmed by ${ }^{13} \mathrm{C}$ NMR spectroscopy data.

The spectral parameters of the peat FA obtained and processed by 13C NMR spectroscopy are presented in Tables 1 and 2 .

Table 1. Fragment compositions of studied FA. Content of $\mathrm{C}$ atoms in the structural fragments (relative integrated areas, \%).

\begin{tabular}{|c|c|c|c|c|c|c|}
\hline $\begin{array}{c}\mathrm{C}=\mathrm{O} \\
(220-185 \mathrm{ppm})\end{array}$ & $\begin{array}{c}\text { COOH, } \\
\text { COOR } \\
(185-165 \text { ppm) }\end{array}$ & $\begin{array}{c}\mathrm{C}_{\mathrm{ar}}-\mathrm{O} \\
(160-140 \mathrm{ppm})\end{array}$ & $\begin{array}{c}\mathrm{C}_{\mathrm{ar}}-\mathrm{H}, \\
\mathrm{C}_{\mathrm{ar}}-\mathrm{C} \\
(140-90 \mathrm{ppm})\end{array}$ & $\begin{array}{c}\mathrm{C}_{\text {alk }}-\mathrm{O} \\
\mathrm{C}_{\alpha \beta}-\mathrm{O}_{4} \\
(90-65 \mathrm{ppm})\end{array}$ & $\begin{array}{c}\mathrm{CH}_{3} \mathrm{O} \\
(65-55 \text { ppm) }\end{array}$ & $\begin{array}{c}C_{\text {alk }} \\
\text { (55-10 ppm) }\end{array}$ \\
\hline 1.13 & 4.60 & 1.05 & 14.82 & 47.70 & 11.73 & 18.97 \\
\hline
\end{tabular}


Table 2. Indicators of the structural features of studied FA.

\begin{tabular}{|c|c|c|c|c|c|c|}
\hline $\begin{array}{c}\text { Total } \\
\text { Aromaticity } \\
f_{a r} \\
\left(f_{a r}=\left(\mathbf{P}_{\text {CarO }}+\right.\right. \\
\left.\left.\mathbf{P}_{\text {CarH,C }}\right)\right)\end{array}$ & $\begin{array}{c}\text { Ratio of } \\
\text { Aromatic and } \\
\text { Aliphatic } \\
\text { Parts } \\
\text { in FA } \\
\text { Car/Calk } \\
\left(\mathrm{C}_{\text {ar }} / \mathrm{C}_{\text {alk }}=\left(\mathrm{P}_{\text {CarO }}+\right.\right. \\
\left.\mathrm{P}_{\text {CarH, }}\right) /\left(\mathrm{C}_{\text {alk }}-\mathrm{O}+\right. \\
\left.\left.\mathrm{CH}_{3} \mathrm{O}+\mathrm{C}_{\text {alk }}\right)\right)\end{array}$ & $\begin{array}{c}\text { Proportion of } \\
\text { Oxygen- } \\
\text { Containing } \\
\text { C Fragments in FA } \\
\mathrm{O} / \mathrm{C} \\
\left(\mathrm{O} / \mathrm{C}=\left(\mathrm{P}_{\mathrm{C}=\mathrm{O}}+\right.\right. \\
2 \mathrm{P}_{\mathrm{COOH}}+\mathrm{P}_{\mathrm{Car}-\mathrm{O}}^{+} \\
1.25 \mathrm{P}_{\mathrm{Calk}-\mathrm{O}}^{+}+ \\
\left.0.5 \mathrm{P}_{\mathrm{CH} 3 \mathrm{O}}\right)\end{array}$ & $\begin{array}{c}\text { Degree of } \\
\text { Oxidation of } \\
\text { the Aromatic } \\
\text { Core of FA } \\
O / \mathrm{C}_{\mathrm{ar}} \\
\left(\mathrm{O} / \mathrm{C}_{\mathrm{ar}}=\right. \\
\mathrm{P}_{\mathrm{Car}-\mathrm{O}} /\left(\mathrm{P}_{\mathrm{CarO}}+\right. \\
\left.\left.\mathrm{P}_{\mathrm{CarH}, \mathrm{C}}\right)\right)\end{array}$ & $\begin{array}{c}\text { Degree of } \\
\text { Oxidation of } \\
\text { Aliphatic } \\
\text { Component } \\
\text { of FA } \\
\mathrm{O} / \mathrm{C}_{\text {alk }} \\
\left(\mathrm{O} / \mathrm{C}_{\text {alk }}=\left(\mathrm{P}_{\text {Calk-O O }}+\right.\right. \\
\left.\mathrm{P}_{\text {CH3O }}\right) /\left(\mathbf{P}_{\text {Calk-O }}+\right. \\
\left.\left.\mathrm{P}_{\text {CH3O }}+\mathbf{P}_{\text {Calk }}\right)\right)\end{array}$ & $\begin{array}{c}\text { Content of } \\
\text { Cydrophilic } \\
\text { Components } \\
\text { HL, \% } \\
\left(\mathbf{P}_{\mathrm{C}=\mathrm{O}}+\mathbf{P}_{\mathrm{COOH}}+\right. \\
\left.\mathbf{P}_{\mathrm{Calk-O}}\right)\left(\mathbf{P}_{\mathrm{C}=\mathrm{O}}+\right. \\
\left.\mathbf{P}_{\mathrm{COOH}}+\mathbf{P}_{\mathrm{Calk}-\mathrm{O}}\right)\end{array}$ & $\begin{array}{c}\text { Content of } \\
\text { Hydrophobic } \\
\text { Components } \\
\text { HB, \% } \\
\left(\mathbf{P}_{\text {Car-H }}+\mathbf{P}_{\text {Car-C }}+\right. \\
\left.\mathbf{P}_{\text {Calk }}\right)\end{array}$ \\
\hline 15.87 & 0.20 & 0.77 & 0.07 & 0.76 & 53.43 & 33.79 \\
\hline
\end{tabular}

The data show that the content of ketone and quinoid groups in FA composition reaches $1.13 \%$, and in carboxyl groups $4.60 \%$ (compared to $0.20 \%$ and $7.38 \%$ in humic acids (HA) isolated from the same peat [2]). The presence of the lignin component (as the most resistant to transformation under conditions of low oxygen access and low biological activity of water bodies) can be identified by the signals $\delta \mathrm{C} \approx 56 \mathrm{ppm}\left(\mathrm{CH}_{3} \mathrm{O}\right.$-groups). The content of $\mathrm{C}_{\text {alk }}-\mathrm{O}$ fragments in the FA sample is rather high (47.7\%), which also indicates the "immaturity" of the peat used to obtain FA (Table 1). The aromaticity index $f_{a r}$ for FA is only 15.87 (and for HA, 40.68 [2]). The content of hydrophobic components in the structure of FA, determined by this method, is $33.79 \%$ (Table 2). Thus, the fulvic acids used contain a significant amount of carboxyl, ketone, and hydroxyl groups, as well as quinoid fragments responsible for the formation of salts and complex compounds with heavy metals [2]. A large number of aliphatic structures suggests an intense interaction of FA with the surface of the minerals, including intercalation into the interlayer space of bentonite.

The results of the FA adsorption process on bentonite and on kaolinite are shown in Figure 1 and in Figure 2, respectively.

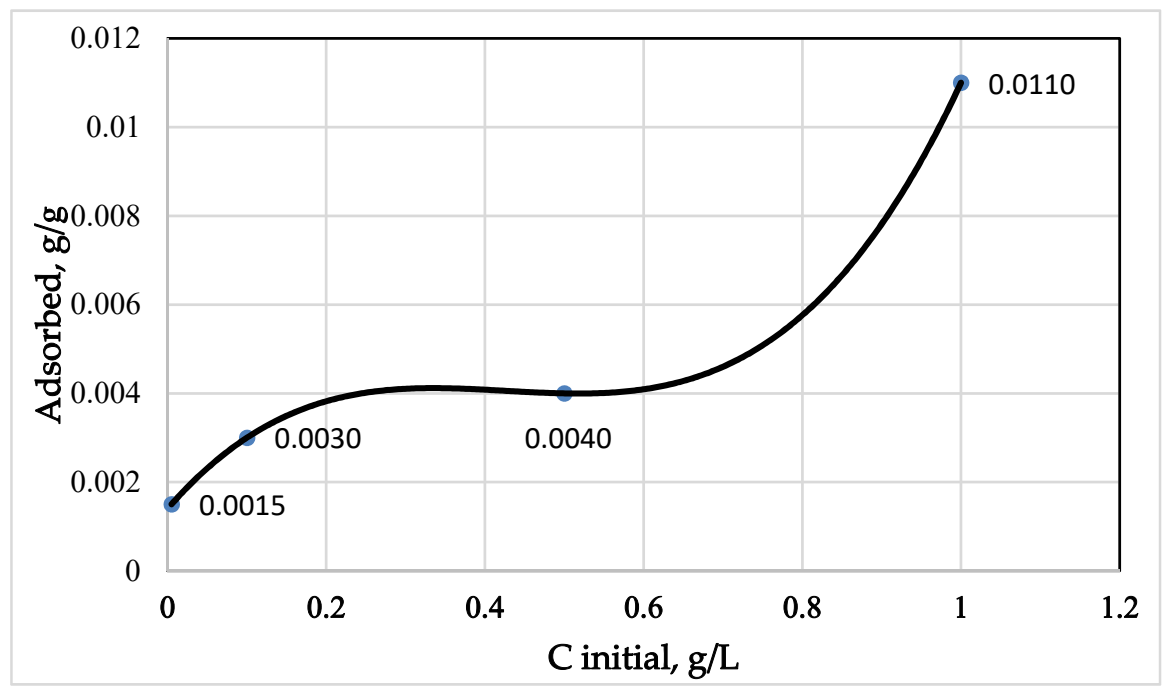

Figure 1. Isotherm of FA adsorption on bentonite. 


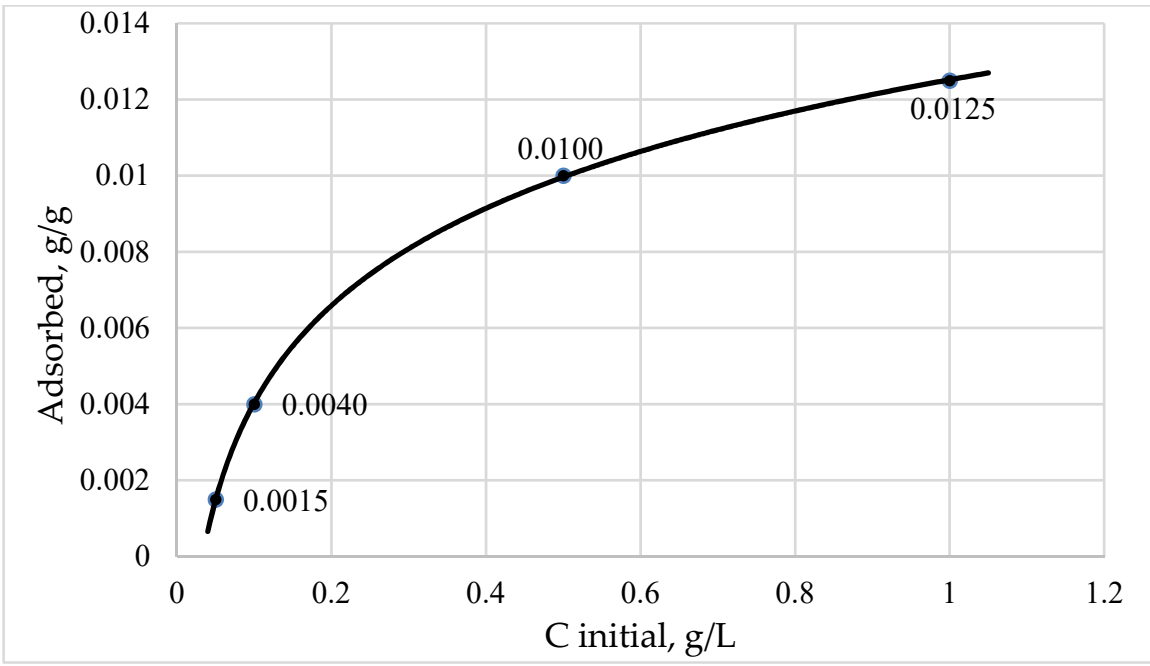

Figure 2. Isotherm of FA adsorption on kaolinite.

Changes of optical density during sorption processes in the systems FA-metal $(\mathrm{Pb}$ or $\mathrm{Zn}$ ) such as in the systems FA-metal (Pb or $\mathrm{Zn})-$ kaolinite and FA-metal ( $\mathrm{Pb}$ or $\mathrm{Zn}$ )bentonite are shown in Figures 3 and 4.

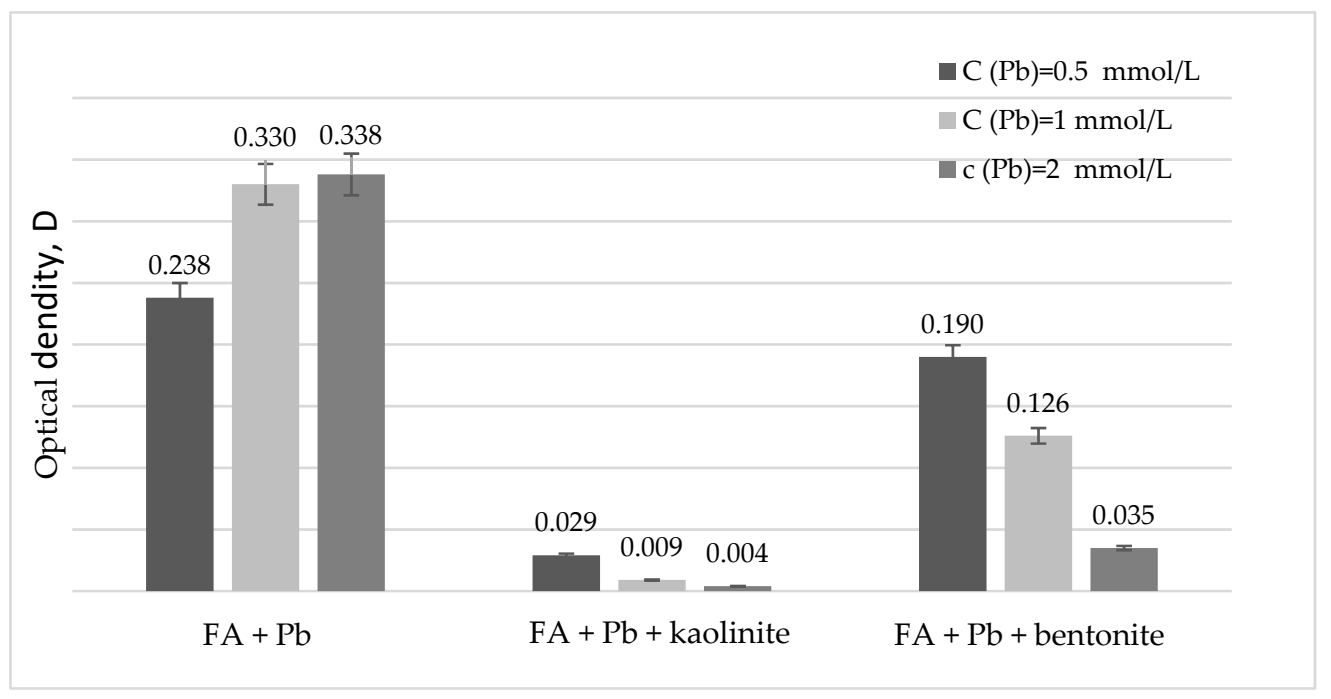

Figure 3. Dependence of the optical density of the studied systems on the $\mathrm{Pb}^{2+}$ concentration. 


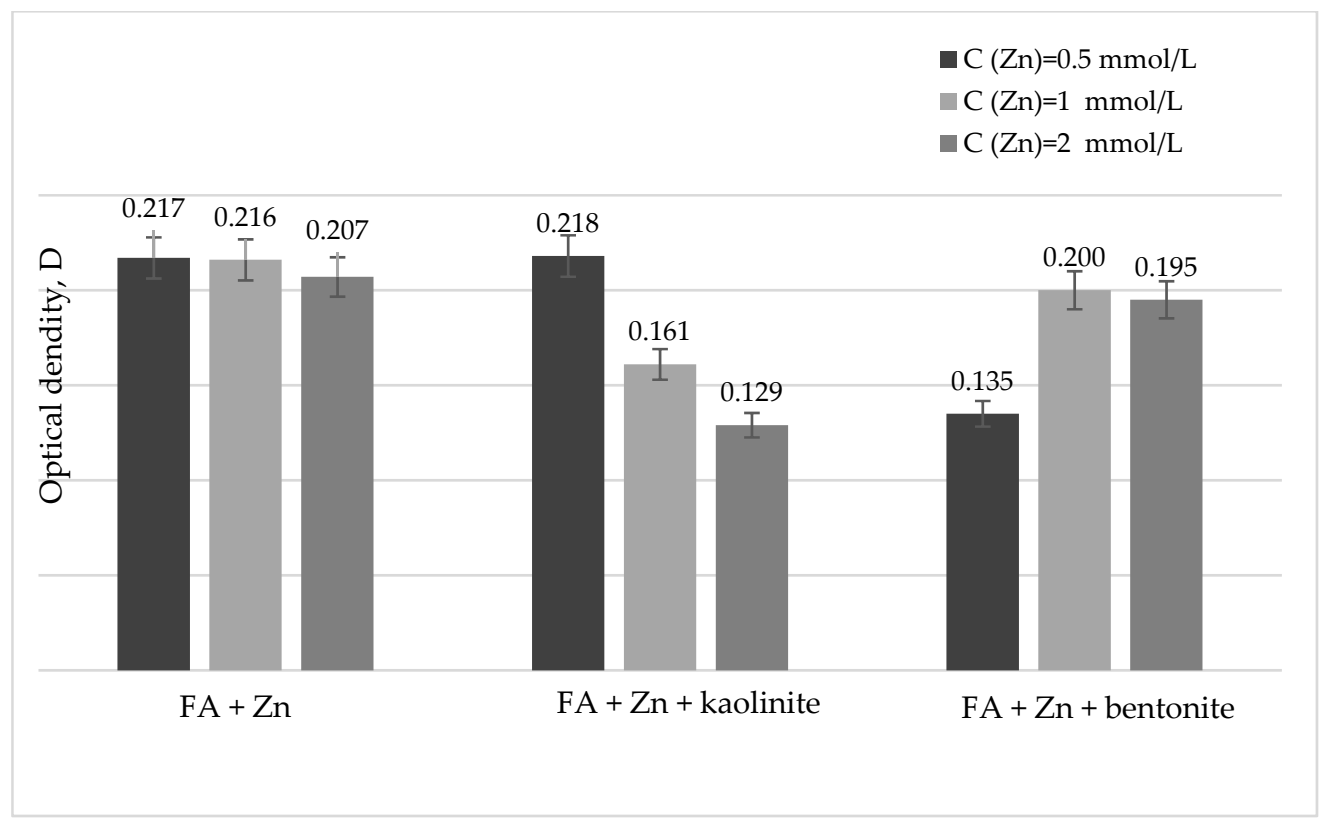

Figure 4. Dependence of the optical density of the studied systems on the $\mathrm{Zn}^{2+}$ concentration.

\section{Discussion}

\subsection{FA Adsorption on Bentonite}

Analysis of our data (Figure 1) suggests that FA adsorption on bentonite occurs by a polymolecular mechanism, since the isotherm can be categorized as belonging to the L3 type according to Giles [26]. Similar isotherms were obtained during the adsorption of polyelectrolytes modeling soil organic matter on montmorillonite [11]. The adsorption of FA on the bentonite surface occurs in three stages. In the initial stage, with an increase of the initial concentration of FA to $0.2 \mathrm{~g} / \mathrm{L}$, FA saturates the most accessible adsorption centers of the clay mineral. The amount of FA absorbed reaches $0.003-0.004 \mathrm{~g} / \mathrm{g}$. In the concentration range from 0.2 to $0.5 \mathrm{~g} / \mathrm{L}$, the adsorption processes stop, or negative adsorption takes place. In general, a part of the obtained isotherm in the range of the initial FA concentrations of $0-0.4 \mathrm{~g} / \mathrm{L}$ resembles the isotherm of monomolecular adsorption of the L1 or L2 type. At this stage, according to some authors, the filling of the adsorbent surface proceeds to the mechanism of specific adsorption [11,27] due to the interaction of polar groups of organic matter with active centers of the mineral's charged surface. This section of the isotherm is rather short, which indicates a limited number of sites for FA-specific adsorption. During specific adsorption, partial or complete straightening of organic molecules on the surface is possible, as well as layer-by-layer filling in the form of supramolecular structures [11,27]. Such adsorption of organic substances in the form of aggregates can lead to their partial desorption from the surface of the mineral at concentrations of $0.4-0.6 \mathrm{~g} / \mathrm{L}$. With an increase in concentration to above $0.6 \mathrm{~g} / \mathrm{L}$, the adsorption of FA by the surface of the bentonite resumes, and further increases with increasing acid concentration, which indicates the formation of a modified bentonite surface during the adsorption of fulvic acids and a change in the interaction mechanism at higher concentrations of organic matter. It is also possible to increase the interlayer space of bentonite due to the partial intercalation of fulvic acid fractions between layers. Our study of changes in the basal reflex $\mathrm{d}_{001}$ upon modification of bentonite with fulvic acids at concentrations of $0.05,0.2$, and $1 \mathrm{~g} / \mathrm{L}$ by X-ray diffraction analysis showed that for concentrations of $0.2 \mathrm{~g} / \mathrm{L}$ and $1 \mathrm{~g} / \mathrm{L}$, we can talk about a decrease in the ordering of the structure of bentonite in the presence of FA-reflections $\mathrm{d}_{003}$ $(5.07 \AA)$ and $\mathrm{d}_{005}(3.11 \AA)$ are present only in the spectrum with the minimum concentration of FA $(0.05 \mathrm{~g} / \mathrm{L})$. At the maximum used concentration $(1 \mathrm{~g} / \mathrm{L})$, a significant shift in the basal reflex is recorded (from 14.48 to $14.73 \AA$ ), which illustrates an increase in the interlayer space of the mineral. 


\subsection{FA Adsorption on Kaolinite}

The isotherm of fulvic acid adsorption on kaolinite is of the L2 type [26] (Figure 2). This isotherm shape indicates that at low concentrations of the adsorbate, it has a relatively high chemical affinity for the adsorbent surface. As the sorption centers are filled, the number of unfilled sorption sites decreases and, accordingly, the amount of adsorbed substance decreases [28]. The authors of [29,30] believed that the binding of humic substances by kaolinite occurs both due to nonspecific as well as specific adsorption. There are interactions between positively charged centers of kaolinite and carboxylic groups, as well as due to hydrophobic binding. In this case, the isotherm demonstrates close saturation of kaolinite, in contrast to the adsorption isotherm of FA on bentonite, which has a sharply ascending form in the region of maximum concentration. Therefore, adsorbance is consistent with the cation exchange capacities of the studied minerals. Thus, for the two-layer and three-layer clay mineral with an expanding structure, adsorption interactions with fulvic acids have pronounced specificity.

\subsection{Adsorption Processes in the Systems FA-Pb-Kaolinite and FA-Pb-Bentonite}

The interaction of FA with metal cations occurs according to the mechanism of formation of mono-, bi- and polydentate complexes, as well as complex compounds of the chelate type. It has been found [31,32] that $\mathrm{Pb}$ forms monodentate complexes, preferably with phenolic sites of FA in a metal: FA ratio of 1: 1, and their stability increases with increasing $\mathrm{pH}$. According to a study of metal speciation in a wide range of different soil solution, $\mathrm{Pb}$ ions are mainly present in complexed form, indicating that they have higher affinity to organic ligands [13]. Fourier transform infrared spectra indicated that two types of functional groups (sites) exist in the FA and participated in the interaction of FA and $\mathrm{Pb}^{2+}$. The apparent stability constant values calculated for the strong binding sites were higher than those for the weak sites by 1-2 orders of magnitude; however, strong sites were limited in number [33].

The data of IR spectrometry and ${ }^{13} \mathrm{C}$ NMR spectroscopy indicate a significant number of functional groups in the composition of the used FA, which can be involved in the formation of complex compounds and salts with $\mathrm{Pb}$. Our results demonstrate that the optical density of the FA and $\mathrm{Pb}$ solution increases with increasing concentration of $\mathrm{Pb}$ ions up to a metal concentration of $1 \mathrm{mmol}$, and then practically does not change (Figure 3 ). This behavior of the system may be due to the formation of colored complex compounds of the metal with FA. The ability of $\mathrm{Pb}$ to interact with a wide range of organic ligands is closely associated with its heavy atom effect, inert lone pair effect, large ionic radius, and its borderline position on the hard-soft acid-base scale [34]. Complexes of Pb with organic ligands exhibit frequently unique optical (including luminescent) properties, which are seldom realized in other metal-organic complexes [35].

In the $\mathrm{FA}-\mathrm{Pb}^{2+}-$ kaolinite and $\mathrm{FA}-\mathrm{Pb}^{2+}$-bentonite systems, the optical density decreases with an increase of the $\mathrm{Pb}$ concentration (Figure 3), which indicates the active adsorption of FA and metal-FA complexes by the clay minerals. Adsorption processes occur more efficiently on kaolinite at all used $\mathrm{Pb}$ concentrations, despite its lower adsorption capacity.

\subsection{Adsorption Processes in the Systems FA-Zn-Kaolinite and FA-Zn-Bentonite}

Results of study by soil column - the Donnan membrane technique for metal speciation in eighteen soil solutions, covering a wide range of metal sources and concentrations, shows that in soil solution, $\mathrm{Zn}$ mainly exists as free ions [13]. Zn is not sensitive to dissolved organic matter reactivity due to its low affinity for FA [36]. Perhaps this explains the absence of optical density changes in the FA- $\mathrm{Zn}^{2+}$ system at all used $\mathrm{Zn}$ concentrations (Figure 4).

Based on the data of optical density of solution changes, the adsorption of complex compounds of $\mathrm{Zn}^{2+}$ with FA on kaolinite increases with increasing concentrations of the metal, which demonstrates the importance of trace element cations in the interaction be- 
tween soil organic matter and the clay mineral. However, in the presence of $\mathrm{Pb}$, absorption by kaolinite proceeds more efficiently than in the presence of $\mathrm{Zn}$.

In the case of bentonite, the low concentration of $\mathrm{Zn}^{2+}$ leads to a decrease in optical density compared to the FA- $\mathrm{Zn}^{2+}$ system, and at a concentration of 1 and $2 \mathrm{mmol} / \mathrm{L}$, the optical density practically does not decrease. Thus, it can be assumed that $\mathrm{Zn}$ promotes the adsorption of fulvic acids by bentonite only at certain low concentrations. It is possible that at the lowest metal concentration used, $\mathrm{Zn}$ promotes the adsorption of FA- $\mathrm{Zn}^{2+}$ complexes through the formation of cation bridges with the mineral surface [18]. At higher concentrations, a more complex behavior of complexes of $\mathrm{Zn}$ and FA is observed, which, based on the absence of a change in optical density, can formally be interpreted as the absence of adsorption.

\section{Conclusions}

Thus, binding of FA and their metal compounds by clay minerals is a complex phenomenon due to the chemical heterogeneity of FA, the different properties of metal ions, and the variability of environmental conditions. The results of studying the adsorption processes of fulvic acids on clay minerals in the absence and presence of heavy metal cations, studied by the measurement of optical density changes, allow us to draw the following conclusions:

The adsorption of FA on the surface of bentonite at the studied concentrations proceeds according to the polymolecular mechanism and has a stepwise character. The isotherm can be classified as L3 type according to Giles. The stepwise adsorption can be explained by the formation of new sorption sites upon modification of the bentonite surface by FA and an increase in the interlayer space due to the partial intercalation of organic molecules. The adsorption of FA by kaolinite can be described by the mechanism of monomolecular adsorption and is the L2 type isotherm in accordance with Giles.

In three-component systems, including FA, trace element ion, and clay mineral complex processes occur, including the formation of complexes and salts and their adsorption. The adsorption of colored compounds of $\mathrm{FA}$ with $\mathrm{Pb}$ on the surface of kaolinite and bentonite increases with increasing metal concentrations. The adsorption of compounds of FA with $\mathrm{Zn}$ is more complex. At $\mathrm{Zn}$ concentration of $0.5 \mathrm{mmol} / \mathrm{L}$ adsorption of the FA-metal compounds take place. At metal concentrations of $1 \mathrm{mmol} / \mathrm{L}$ and $2 \mathrm{mmol} / \mathrm{L}$, based on the absence of optical density changes, we can formally assume the absence of FA-metal salt and complex adsorption by bentonite.

Author Contributions: Conceptualization, M.N. and L.P.; methodology, L.P.; investigation, P.T., L.M. and E.I.; writing—original draft preparation, L.P.; writing—review and editing, Y.A.; visualization, M.N.; supervision, Y.A.; funding acquisition, L.P. All authors have read and agreed to the published version of the manuscript.

Funding: This research was funded by the Grant of the government of the Tula region in the field of science and technology (2021-2022 years), agreement number ДС/262. The APC was waived by "Soil Systems".

Institutional Review Board Statement: Not Applicable.

Informed Consent Statement: Not Applicable.

Data Availability Statement: Not Applicable.

Acknowledgments: The authors are grateful to the Resource Center "Magnetic Resonance Research Methods" of St. Petersburg State University and to Professor Alekseeva T.V. from the Institute of Physicochemical and Biological Problems in Soil Science of RAS for assistance in conducting of the analytical work.

Conflicts of Interest: The authors declare no conflict of interest. 


\section{References}

1. Perelomov, L.V.; Sizova, O.I.; Atroshchenko, Y.M. Adsorption of trace elements by bentonite in the presence of bacteria. Geochem. Int. 2019, 57, 290-297. [CrossRef]

2. Perelomov, L.; Sarkar, B.; Pinsky, D.; Atroshchenko, Y.; Perelomova, I.; Mukhtorov, L.; Mazur, A. Trace elements adsorption by natural and chemically modified humic acids. Environ. Geochem. Health 2021, 43, 127-138. [CrossRef]

3. Kloster, N.; Avena, M. Interaction of humic acids with soil minerals: Adsorption and surface aggregation induced by $\mathrm{Ca}^{2+}$. Environ. Chem. 2015, 12, 731-738. [CrossRef]

4. Kumar, A.; Lingfa, P. Sodium bentonite and kaolin clays: Comparative study on their FT-IR, XRF, and XRD. Mater. Today Proc. 2020, 22, 737-742. [CrossRef]

5. Osipov, V.I.; Sokolov, V.N.; Rumyantseva, N.A. Microstructure of Clay Rocks; Nedra: Moscow, Russia, 1989. (In Russian)

6. Pokidko, B.V.; Bukanova, E.F.; Tutorsky, I.A.; Il'ina, M.B. Influence of $\mathrm{Ca}^{2+}$ on the adsorption of different surfactants in the bentonite-water interface. Fine Chem. Technol. 2009, 4, 77-83. (In Russian)

7. Ammann, L.; Bergaya, F.; Lagaly, G. Determination of the cation exchange capacity of clays with copper complexes revisited. Clay Miner. 2005, 40, 441-453. [CrossRef]

8. Perelomov, L.; Mandzhieva, S.; Minkina, T.; Atroshchenko, Y.; Perelomova, I.; Bauer, T.; Barakhov, A. The synthesis of organoclays based on clay minerals with different structural expansion capacities. Minerals 2021, 11, 707. [CrossRef]

9. Liu, A.; Gonzalez, R.D. Adsorption/desorption in a system consisting of humic acid, heavy metals, and clay minerals. J. Colloid. Interface Sci. 1999, 218, 225-232. [CrossRef] [PubMed]

10. Huang, P.M.; Violante, A. Influence of organic acids on crystallization and surface properties of precipitation products of aluminum. In Interactions of Soil Minerals with Natural Organics and Microbes; Huang, P.M., Schnitzer, M., Eds.; SSSA: Madison, WI, USA, 1986; pp. 159-221.

11. Kurochkina, G.N.; Pinskii, D.L. Development of a mineralogical matrix at the adsorption of polyelectrolytes on soil minerals and soils. Eurasian Soil Sci. 2012, 45, 1057-1067. [CrossRef]

12. Groenenberg, J.E.; Koopmans, G.F.; Comans, R.N.J. Uncertainty analysis of the nonideal competitive adsorption-Donnan model: Effects of dissolved organic matter variability on predicted metal speciation in soil solution. Environ. Sci. Technol. 2010, 44, 1340-1346. [CrossRef] [PubMed]

13. Ren, Z.-L.; Tella, M.; Bravin, M.N.; Comans, R.N.J.; Dai, J.; Garnier, J.-M.; Sivry, Y.; Doelsch, E.; Straathof, A.; Benedetti, M.F. Effect of dissolved organic matter composition on metal speciation in soil solutions. Chem. Geol. 2015, 398, 61-69. [CrossRef]

14. Stevenson, F.J. Humus Chemistry: Genesis, Composition, Reactions, 2nd ed.; Wiley: New York, NY, USA, 1994.

15. Ghabbour, E.A.; Davies, G. Spectrophotometric analysis of fulvic acid solutions-A second look. Ann. Environ. Sci. 2009, 3, 131-138.

16. Violante, A.; Krishnamurti, G.S.R.; Pigna, M. Factors affecting the sorption-desorption of trace elements in soil environments. In Biophysico Chemical Processes of Heavy Metals and Metalloids in Soil Environments; Violante, A., Huang, P.M., Gadd, G.M., Eds.; Wiley-IUPAC: New York, NY, USA, 2007; pp. 169-214.

17. Perelomov, L.V.; Pinskiy, D.L.; Violante, A. Effect of organic acids on the adsorption of copper, lead, and zinc by goethite. Eurasian Soil Sci. 2011, 44, 22-28. [CrossRef]

18. Elliot, H.A.; Huang, C.P. Adsorption characteristics of some $\mathrm{Cu}(\mathrm{II})$ complexes on aluminosilicates. Water Res. 1981, 15, 849-855. [CrossRef]

19. Zhou, Y.; Zhang, Y.; Li, G.; Jiang, T. Effects of metal cations on the fulvic acid (FA) adsorption onto natural iron oxide in iron ore pelletizing process. Powder Technol. 2016, 302, 90-99. [CrossRef]

20. Ye, Y.; Chen, Z.; Montavon, G.; Jin, Q.; Guo, Z.; Wu, W. Surface complexation modeling of Eu(III) adsorption on silica in the presence of fulvic acid. Sci. China Chem. 2014, 57, 1276-1282. [CrossRef]

21. Schnitzer, M.; Kodama, H. Reactions between fulvic acid and $\mathrm{Cu}^{2+}$-montmorillonite. Clays Clay Miner. 1972, $20,359-367$. [CrossRef]

22. Lowe, L.E. Studies on the nature of sulphur in peat humic acids from the Fraser river delta British Columbia. Sci. Total Environ. 1992, 113, 133-145. [CrossRef]

23. Jarukas, L.; Ivanauskas, L.; Kasparaviciene, G.; Baranauskaite, J.; Marksa, M.; Bernatoniene, J. Determination of organic compounds, fulvic acid, humic acid, and humin in peat and sapropel alkaline extracts. Molecules 2021, 26, 2995. [CrossRef]

24. Orlov, D.S. Soil Chemistry; Russian Translation Series 92; CRC Press: Boca Raton, FL, USA, 1992.

25. Byler, D.M.; Gerasimowicz, W.V.; Susi, H.; Schnitzer, M. FT-IR Spectra of soil constituents: Fulvic acid and fulvic acid complex with ferric ions. Appl. Spectrosc. 1987, 41, 1428-1430. [CrossRef]

26. Giles, C.H.; Smith, D.; Huitson, A. A general treatment and classification of the solute adsorption isotherm. I. Theoretical. J. Colloid Interface Sci. 1974, 47, 755-765. [CrossRef]

27. Lipatov, Y.S.; Sergeeva, L.M. Adsorption of Polymers; Naukova Dumka: Kiev, Russia, 1972. (In Russian)

28. Sokolova, T.A.; Trofimov, S.Y. Sorption Properties of Soils. Adsorption. Cation Exchange: A Textbook on Some Chapters of Soil Chemistry; Grif and K: Tula, Russia, 2009. (In Russian)

29. Balnois, E.; Wilkinson, K.J.; Lead, J.R.; Buffle, J. Atomic force microscopy of humic substances: Effects of pH and ionic strength. Environ. Sci. Technol. 1999, 33, 3911-3917. [CrossRef] 
30. Sokolowska, Z.; Sokolowski, S. Influence of humic acid on surface fractal dimension of kaolin: Analysis of mercury porosimetry and water vapour adsorption data. Geoderma 1999, 88, 233-249. [CrossRef]

31. Christl, I.; Milne, C.J.; Kinniburgh, D.G.; Kretzschmar, R. Relating ion binding by fulvic and humic acids to chemical composition and molecular size. Metal binding. Environ. Sci. Technol. 2001, 35, 2512-2517. [CrossRef]

32. Rey-Castro, C.; Mongin, S.; Huidobro, C.; David, C.; Salvador, J.; Garcés, J.L.; Galceran, J.; Mas, F.; Puy, J. Effective affinity distribution for the binding of metal ions to a generic fulvic acid in natural waters. Environ. Sci. Technol. 2009, 43, 7184-7191. [CrossRef]

33. Wang, J.; Lü, C.; He, J.; Zhao, B. Binding characteristics of $\mathrm{Pb}^{2+}$ to natural fulvic acid extracted from the sediments in Lake Wuliangsuhai, Inner Mongolia plateau, P.R. China. Environ. Earth Sci. 2016, 75, 768. [CrossRef]

34. Chu, W.; Sun, Z.-G.; Jiao, C.-Q.; Zhu, Y.-Y.; Sun, S.-H.; Tian, H.; Zheng, M.J. Two novel lead (ii) carboxyphosphonates with a layered and a 3D framework structure: Syntheses, crystal structures, reversible dehydration/hydration, and luminescence properties. Dalton Trans. 2013, 42, 8009-8017. [CrossRef] [PubMed]

35. Wang, L.-X.; Xiang, J.; Li, C.-H.; Leung, C.-F.; Xiang, J. Recent advances on the applications of luminescent Pb ${ }^{2+}$-containing metal-organic frameworks in white-light emission and sensing. Front. Chem. 2021, 9, 636431. [CrossRef]

36. Vega, F.A.; Weng, L. Speciation of heavy metals in River Rhine. Water Res. 2013, 47, 363-372. [CrossRef] 